\title{
The importance of nummulites and assilina in the correlation of middle and upper Eocene rocks
}

\author{
Ghazala Roohi* and SRH Baqri \\ Earth Sciences Division, Pakistan Museum of Natural History (PMNH), Garden Avenue, Shakarparian, Islamabad, PAKISTAN \\ * To whom the correspondence should be addressed. E-mail: roohighazala@yahoo.com
}

\begin{abstract}
The abundance and identification of the fossil forams was investigated in the Kohat Formation (U. Eocene), Kuldana Formation (U. Eocene) and theChorgali Formation (M. Eocene) exposed in Kala Chitta and Margalla Ranges and representing the unstable and fluctuating environments of the vanishing Tethys Sea during the collision of thelndian and Eurasian subcontinents. The KohatFormation and Kuldana Formation aremissingfurther south towards the Salt Range where the marls and argillaceous limestones of theChorgali Formation are unconformiblyoverlain by the continental sediments of Rawalpindi Group of Miocene age. The limestones and marls of the oldest Chorgali Formation and youngest Kohat Formation represent marineenvironments with abundant fossil forams and other marine fauna, while the red shales and sandstones sandwiches Kuldana Formation display continental environments with vertebrate fossils of mammalsand reptiles. The Kuldana Formation also occasionally displays thin bands of limestones/marls, representing the unstableenvironmental conditions.
\end{abstract}

The detailed studies of fossils forams in these formations indicate the presence of mostly nummulites and assilina. The nummulites are abundant and dominant in the Chorgali Formation and in band intercalated with the continental sediment of the Kuldana Formation while assilina are subordinate. On theother hand, theassilina are dominant in the Kohat Formation with subordinatenummulites.

Thefossil foramsfound in theEocenerocks exposed in Kala Chitta Range, Margalla Rangeand Salt Rangewere compared and correlated with the forams found in the top beds of the Kirthar Formation, exposed further south at a distance of morethan 1000 km, at Kotdiji , Khairpur and Rohri in the Sindh Province of Pakistan. The abundant limestone abundantly in Kirthar Formation displaymostly with someassilina. It is most likely that the nummulites beds at the top of Kirthar Formation represent the same environment and time as the Chorgali and Kuldana Formations exposed in the north and younger beds at the top of KirtharFormation are equivalent to KohatFormation wereeroded away during uplifting in the Oligocenetimes. 